\author{
Research article \\ urn:1sid:zoobank.org:pub:FF6AA834-7ED0-4A59-8D95-35836EB8D281
}

\title{
New discoveries for the subfamily Phtisicinae Vassilenko, 1968 (Crustacea: Senticaudata) from the Brazilian coast
}

\author{
Fábio da Motta MAURO ${ }^{1, *}$, Priscila Soares do NASCIMENTO ${ }^{2}$ \& \\ Cristiana Silveira SEREJO ${ }^{3}$ \\ 1,2,3 Programa de Pós-Graduação em Ciências Biológicas (Zoologia), Museu Nacional/Universidade \\ Federal do Rio de Janeiro, RJ, 20940-040, Brazil. \\ 1,2,3 Museu Nacional, Universidade Federal do Rio de Janeiro, Laboratório de Carcinologia, \\ RJ, 20940-040, Brazil. \\ *Corresponding author: fabiologia87@gmail.com \\ 2Email: nascimentops23@gmail.com \\ ${ }^{3}$ Email: csserejo@acd.ufrj.br \\ ${ }^{1}$ urn:1sid:zoobank.org:author:EA6D510C-FCB8-424C-B05F-86A60A3C0C4 \\ ${ }^{2}$ urn:lsid:zoobank.org:author:2B1ADA77-D153-4C76-A258-1F67B11D2C85 \\ ${ }^{3}$ urn:1sid:zoobank.org:author:A86225AE-51C8-4D01-9D3E-60FB5B1FE85C
}

\begin{abstract}
Amphipod material collected from Brazil on Ilha do Arvoredo, (Santa Catarina), Campos Basin, (Rio de Janeiro) and Espírito Santo Basin (Espírito Santo) in the southwestern Atlantic Ocean yielded new taxonomic findings for the subfamily Phtisicinae Vassilenko, 1968. Hemiproto wigleyi McCain, 1968, previously recorded from the Gulf of Mexico to the Caribbean Sea, is herein redescribed and recorded for the first time from the Brazilian coast. The type material of Phtisica verae Quitete, 1979, a poorly described species recorded from Brazil and based only on its original description, was examined and considered herein as a junior synonym of P. marina Slabber, 1769, a well-known and widely distributed species from the Atlantic Ocean and the Mediterranean Sea. In this paper, Phtisica marina is redescribed, with its two morphotypes of male gnathopod two, and compared with previous descriptions. The geographic distribution of both $H$. wigleyi and $P$. marina is provided.
\end{abstract}

Keywords. Crustacea, taxonomy, redescription, Caprellidae, Atlantic.

Mauro F.M., Nascimento P.S. \& Serejo C.S. 2020. New discoveries for the subfamily Phtisicinae Vassilenko, 1968 (Crustacea: Senticaudata) from the Brazilian coast. European Journal of Taxonomy 597: 1-17. https://doi.org/10.5852/ejt.2020.597

\section{Introduction}

Caprellids are one of the frequently groups of Crustacea inhabiting mainly shallow water ecosystems, especially in tropical to temperate regions (Takeuchi \& Lowry 2015). They are part of an amphipod group that exhibits degenerated abdomens and pereopods 3-4 variously reduced (Barnard \& Karaman 1991; Laubitz 1993; Ito et al. 2008). However, their classification has changed over the last 30 years 
as a result of some controversial evolutionary scenarios (Laubitz 1976, 1993; Takeuchi 1993; Ito et al. 2008). The former suborder Caprellidea Leach, 1814 comprised seven families: Caprellidae Leach, 1814, Caprellinoididae Laubitz, 1993, Caprogammaridae Kudrjaschov \& Vassilenko, 1966, Paracercopidae Vassilenko, 1968, Pariambidae Laubitz, 1993, Phtisicidae Vassilenko, 1968 and Protellidae McCain, 1970. Laubitz (1993) proposed an evolutionary scenario based on a combination of character states of the mouthparts, pereopods 3-4 and degrees of abdomen reduction, treating the Caprellidea as a polyphyletic group that branched into two distinct lineages, thus forming two groups. Group one consists of Paracercopidae, Caprellinoididae, Cyamidae Rafinesque, 1815 and Phtisicidae whereas group two consists of Caprogammaridae, Caprellidae, Protellidae and Pariambidae. Later, Laubitz (1993) suggested that phtisicids must have split before the paracercopids were established due to unique characters, such as multiarticulate flagellum of antenna two, accessory cutting plates on the mandible, chisel-like teeth on the maxilliped inner plate and fully-developed 6-articulate pereopods 3-4. The fully-developed and functional pereopods 3-4 of the Phtisicidae are a unique character state among the caprellids and, therefore, imply the reacquisition or multiple losses of pereopods 3-4 within caprellid lineages (Ito et al. 2011). Myers \& Lowry (2003) reestablished the relationship of the caprellids within the corophioids and treated them within the suborder Corophioidea Leach, 1814, which includes the superfamily Caprelloidea Leach, 1814 with five families, namely Caprellidae (including subfamilies Caprellinae Leach, 1814, Paracercopinae Vassilenko, 1972 and Phtisicinae Vassilenko, 1968), Caprogammaridae, Cyamidae, Dulichiidae Dana, 1849 and Podoceridae Leach, 1814. More recently, the family Caprellidae was accepted as part of the recently erected suborder Senticaudata Lowry \& Myers, 2013, infraorder Corophiida, superfamily Caprelloidea, including the same five families assigned previously (Lowry \& Myers 2013, 2017). This classification is followed in the present study, although many arguments regarding molecular and morphological aspects have been presented against the validity of the suborder Senticaudata, which remains controversial. (Verheye et al. 2015; d'Udekem d'Acoz \& Verheye 2017).

The family Caprellidae Leach, 1814 has nearly 430 described species, distributed in 90 genera and three subfamilies, namely Caprellinae Leach, 1814 (58 genera), Paracercopinae Vassilenko, 1972 (three genera), and Phtisicinae Vassilenko, 1968 (29 genera) (Horton et al. 2018).

Along the Brazilian coast, 25 Caprellidae species have been recorded to date, including two species of the subfamily Phtisicinae: Phtisica marina Slabber, 1769, widely distributed in the Atlantic Ocean and the Mediterranean Sea, and Phtisica verae Quitete, 1979, a poorly described species, with records based only on its original description from Angra dos Reis, RJ and Ubatuba, SP (Quitete 1979; Mauro \& Serejo 2015; Serejo \& Siqueira 2018). In the present study, we examined the type material of $P$. verae and concluded that it is a junior synonym of P. marina. Furthermore, Hemiproto wigleyi McCain, 1968, previously from Florida, Gulf of Mexico, and the Caribbean Sea (LeCroy et al. 2009; Martin et al. 2013) is redescribed and recorded from the first time for the Brazilian coast, in the Espírito Santo Basin.

\section{Material and methods}

Samples of Phtisica marina and Hemiproto wigleyi were provided from two projects coordinated by CENPES/PETROBRAS: 1. Project HABITATS (Environmental Heterogeneity of the Campos Basin) with samples collected from the Campos Basin (25-150 m) from 2008 to 2009, using a Van Veen grab $92 \times 80 \times 40 \mathrm{~cm}$ (Ribeiro-Ferreira et al. 2017); 2. Project AMBES (Marine environmental characterization of the Espírito Santo Basin and north of the Campos Basin portion) with samples collected from the Espírito Santo Basin and north of the Campos Basin portion (12-150 m) from 2010 to 2013, using a Van Veen grab $92 \times 80 \times 40 \mathrm{~cm}$ and Box Corer $50 \times 50 \times 50 \mathrm{~cm}$. Additionally, the type material of $P$. verae was loaned from the collection of the Department of Zoology/Instituto de Biologia/UFRJ (CDZRJ) and examined for comparison. In addition, some samples from Ilha do Arvoredo, Santa Catarina, were examined and included in the present analysis. 
All material was preserved in $70 \%$ ethanol and deposited in the Crustacean Collection of the Museu Nacional (MNRJ). Due to the brittleness of the caprellidean body, the posterior legs (pereopods 5-7) often drop off during the sampling process and they were missing in most samples. The specimens were examined using notes on their most informative and well-preserved features. The most suitable specimens were selected for drawing and dissection. Specimens were dissected under a stereo microscope. Appendages and mouthparts were mounted on glass slides with gelatin-glycerol and illustrated with camera lucida using the optic microscope ZEISS Axioscope. The setal formula used for the last article of the mandibular palp complies with the formula proposed by McCain (1968). For general caprellid morphological nomenclature, see Guerra-García (2006).

\section{List of abbreviations used in the figures:}

$\begin{array}{ll}\text { abd } & =\text { abdomen } \\ \mathrm{gn} & =\text { gnathopod } \\ \mathrm{h} & =\text { head } \\ \mathrm{lb} & =\text { labium } \\ \mathrm{lbr} & =\text { labrum } \\ \mathrm{mdb}(1) & =\text { left mandible } \\ \mathrm{mdb}(\mathrm{r}) & =\text { right mandible } \\ \mathrm{mdb}(\mathrm{p}) & =\text { mandible palp } \\ \mathrm{mx} & =\text { maxilla } \\ \mathrm{mxp} & =\text { maxilliped } \\ \mathrm{p} & =\text { pereopod } \\ \mathrm{pl} & =\text { pleopod } \\ \mathrm{pln} & =\text { pleon } \\ \mathrm{pn} & =\text { pereonite }\end{array}$

\section{Results}

\section{Systematics}

Class Malacostraca Latreille, 1802

Order Amphipoda Latreille, 1816

Suborder Senticaudata Lowry \& Myers, 2013

Family Caprellidae Leach, 1814

Subfamily Phtisicinae Vassilenko, 1968

\section{Diagnosis}

Antenna flagellum with up to 14 articles, with swimming setae present only on last 2-3 articles; molar absent, incisor 6-toothed, gill plates present on pereonites 2-4; pereopods 3-4 6-articulate; pereopod 5-6-articulate (adapted from Myers \& Lowry 2003).

\section{Genus Hemiproto McCain, 1968}

Included species: Hemiproto wigleyi McCain, 1968 (type species by monotypy).

\section{Diagnosis}

Flagellum of antenna 2 2-4-articulate; swimming setae absent; mandibular palp 3-articulate; setal formula for terminal articles $1-\mathrm{x}-1$ or $1-1$; outer plate of maxilliped equal to inner plate; pereopods 3-4 6-articulate, pereopod 5 -articulate; male abdomen with two pairs of small 1-articulate appendages, female abdomen with one pair of small 1-articulate appendages (adapted from McCain 1968). 


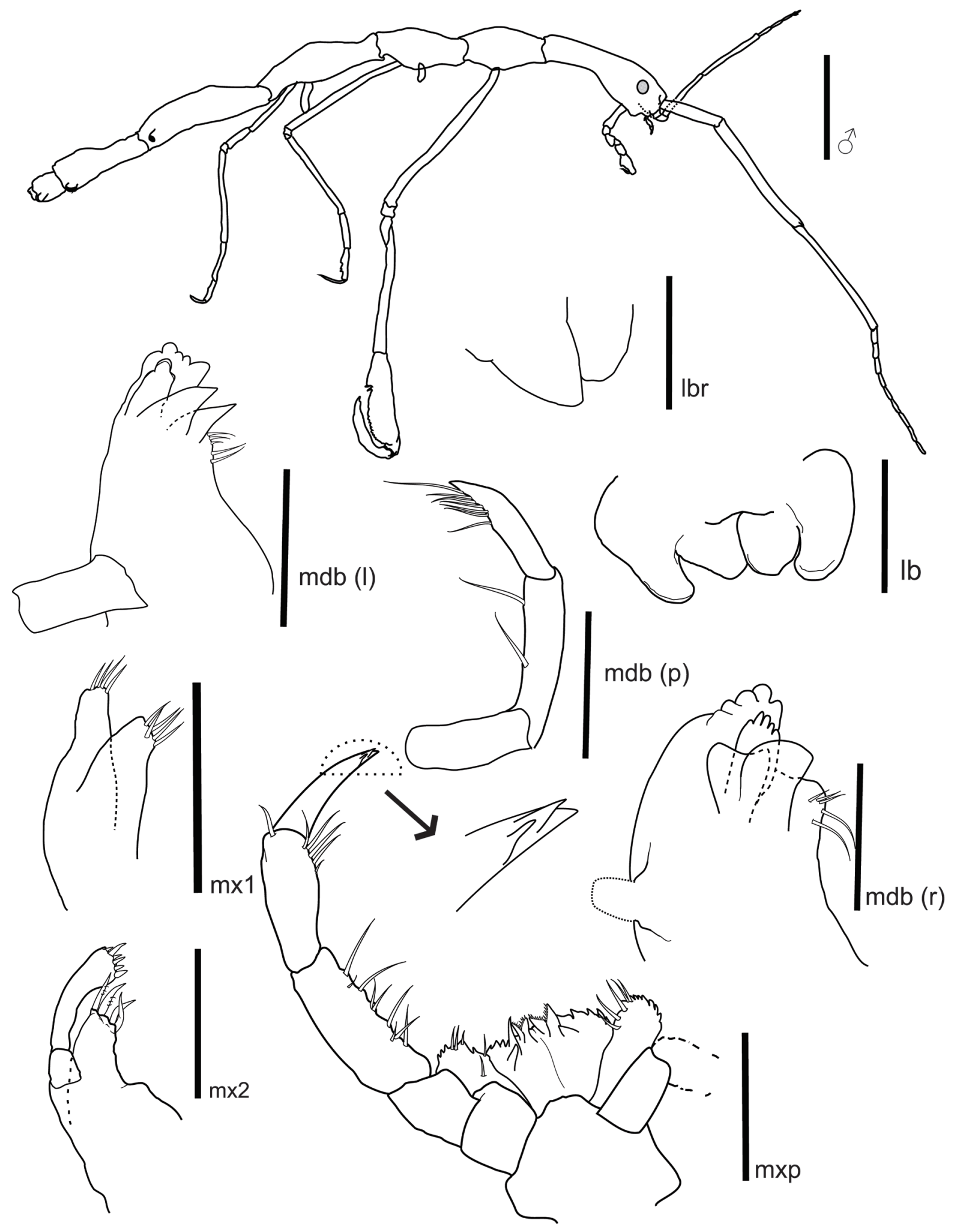

Fig. 1. Hemiproto wigleyi (McCain, 1968). Male, $8.36 \mathrm{~mm}$, Campos Basin, RJ (MNRJ 25515). Scale bars: habitus $=0.5 \mathrm{~mm} ; 1 \mathrm{~b}, 1 \mathrm{br}, \mathrm{mx} 1, \mathrm{mx} 2, \mathrm{mdb}(1), \mathrm{mdb}(\mathrm{r}), \mathrm{mxp}=0.1 \mathrm{~mm}$. 


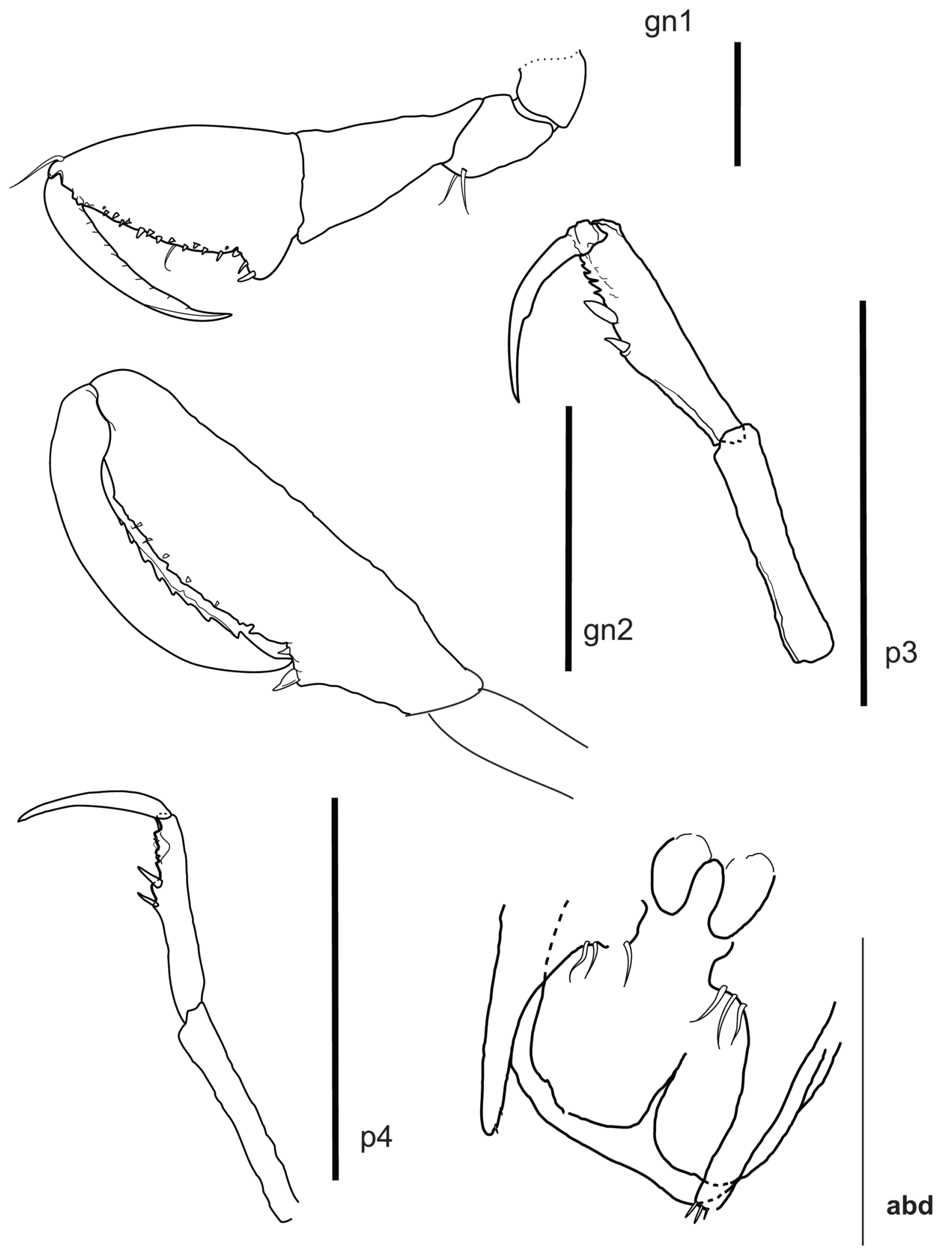

Fig. 2. Hemiproto wigleyi (McCain, 1968). Male, $8.5 \mathrm{~mm}$, Campos Basin, RJ (MNRJ 25515). Scale bars: gn 1 , abd $=0.1 \mathrm{~mm}$; gn2, p3, p4 $=0.1 \mathrm{~mm}$. 
Hemiproto wigleyi McCain, 1968

Figs 1-2

Hemiproto wigleyi McCain, 1968: 65, figs 31, 32C-E, 50.

Hemiproto wigleyi - McCain \& Steinberg 1970: 51. — Díaz et al. 2005: 24, fig. 15. — Winfield et al. 2006: 102. — LeCroy et al. 2009: 965. — Ortíz \& Lalana 2010: 87. — Martin et al. 2013: 1703 . Winfield \& Ortiz 2013: 167.

\section{Diagnosis}

Antenna 1 slightly smaller than body length, flagellum with nine articles, articles 2-3 much longer than article 1. Antenna 2 flagellum with four articles. Gill pairs on pereonites $2-4$.

\section{Material examined}

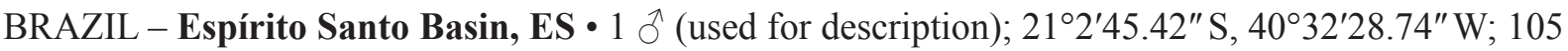

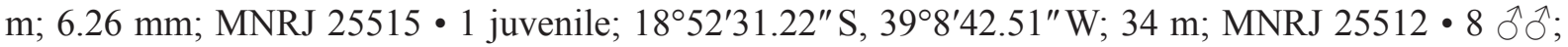

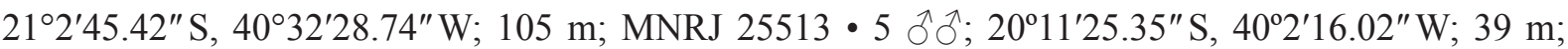

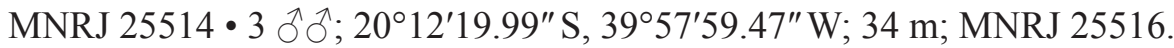

\section{Redescription}

HEAD. Left mandible with 5-toothed incisor, 5-toothed lacinia mobilis, and two accessory plates, row of eight lateral setae; palp 3-articulate, last article setal formula 1-5-1. Right mandible with 5-toothed incisor, lacinia mobilis smooth, two accessory plates and a row of five slender setae; labium outer lobe wing-shaped, inner lobe small. Labrum apically acute. Maxilla 1 outer lobe with four robust apical setae, palp with six robust apical setae. Maxilliped palp second article with six lateral setae and two very small setae inserted at medium-lateral part, article 3 with distal row of five setae; distal article with three toothlike apical projections; outer plate serrate, four setae at top and one inserted at middle border; inner plate strongly serrate with pair of two pectinate acute projections at medial-distal apex, pair of robust setae on ventral-medial part.

Thorax. Gnathopod 1 carpus much longer than ischium and merus, expanding from middle, largest width at distal part; propodus with three proximal grasping setae, palm with about 12 small and robust setae, dactylus smooth. Gnathopod 2 carpus strongly elongate, propodus with two proximal grasping setae, proximal subquadrate indent, palm irregularly serrate, three times as long as wide; dactylus strongly serrate. Pereopods 3-4 merus longer than following articles, with two proximal robust setae, and serrate projections distally; dactylus smooth. Pereopods 5-7 missing.

ABDomen. One pair of small anterior pyriform, appendages; pair of lobes smooth and pair of very elongate posterior appendages, 1-articulate, with three proximal and three distal setae.

\section{Distribution (Figs 6-7)}

Type locality: Hancock Atlantic Expedition sta. A32-39, 3 miles N. Coche Island, Nueva Sparta, Venezuela, 35-60 m (McCain 1968). Other localities: Atlantic Ocean: Fort Lauderdale, Florida; California (McCain 1968); Santa Maria Basin region, Florida (Watling 1997), Falcón, Venezuela (Díaz et al. 2005), Gulf of Mexico (LeCroy et al. 2009; Winfield et al. 2006, Winfield \& Ortiz 2013), Caribbean Sea (Ortíz \& Lalana 2010; Martin et al. 2013). Brazil: Espírito Santo Basin, Brazil (present study). Depth range: 32-105 m (Díaz et al. 2005; Ortíz \& Lalana 2010; present study). 
MAURO F.M. et al., Subfamily Phtisicinae from the Brazilian Coast

Genus Phtisica Slabber, 1769

Included species: Phtisica antillensis (Mayer, 1903); Phtisica marina Slabber, 1769.

\section{Diagnosis}

Antenna 2 flagellum 2-5 articulate. Swimming setae absent. Mandible palp 3-articulate, setal formula $1-\mathrm{x}-\mathrm{y}-1$, molar absent. Maxilliped external plate equal to or little larger than outer plate. Pereopods 3-4 6-articulate, pereopod 5 -articulate. Male abdomen with two lobes, three pair of appendages. Female abdomen with two appendages and pair of lobes (modified from McCain 1968).

Phtisica marina Slabber, 1769

Figs $3-5$

Phtisica marina Slabber, 1769: 79, figs 1-3; type locality: Zeeland.

Proto elongatus Dana, 1853: 810, pl. 54, fig. 1.

Phtisica verae Quitete, 1979: 6-7; figs 1, 2.

Phtisica marina - Sars 1895: 646-648, figs 233. - McCain 1968: 91, figs 46-47 (see extensive synonymy). — Krapp-Schickel 1993: 806, figs 549-550. — Conradi et al. 1997: 98-110. — Serejo 1998a: 381. — Wakabara \& Serejo 1998: 582. — Winfield et al. 2006: 102. — LeCroy et al. 2009: 965. — Lacerda \& Masunari 2011: 372, figs 3c; 10. — Martin et al. 2013: 1703. — Mauro \& Serejo 2015: 124 (key).

Proto ventricosa - Oliveira 1940: 140.

Phtisica verae - Wakabara \& Serejo 1998: 582. — Lacerda \& Massunari 2011: 366.

\section{Diagnosis}

Body smooth, head about same as long as pereonite 2 length. Antenna 1 variable in length, from 0.5 times body length to equal. Pereonites $2-4$ with pairs of gills, first pair smaller. Pereopods $3-4$ propodus with 4-5 robust setae. Morphotype I gnathopod 2 merus and carpus not expanded, palm slightly membranous, lobes absent; pereopod 3 dactylus with single setae row. Morphotype II gnathopod 2 merus and carpus slightly expanded, propodus with 3-4 membranous lobes. Male abdomen with pair of 2-articulate appendages and one pair of pyriform appendages.

\section{Material examined}

BRAZIL - Rio de Janeiro • 1 ( (used for description of morphotype II); Angra dos Reis; 24 m;

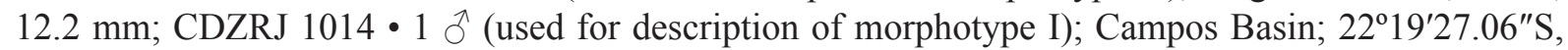

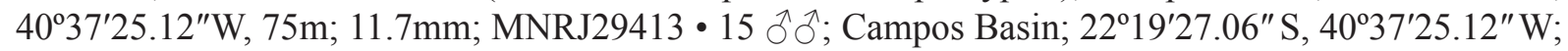

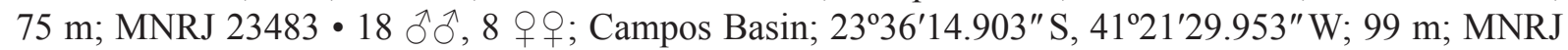

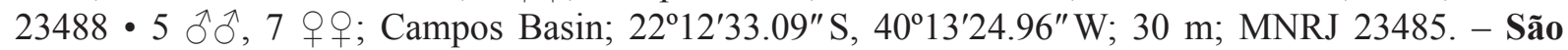
Paulo 1 i (P. verae allotype); Ubatuba, Enseada do Flamengo; 20 m; 9.8 mm; CDZRJ 1012 - Santa Catarina $\bullet 1$ ô, 1 q; Ilha do Arvoredo; 3 m; MNRJ 19421

\section{Redescription}

HEAD. Labrum outer and inner lobes well demarcated, inner lobe rounded and solid, with row of minute setae. Maxilla 1 outer lobe with five setae and two minute, robust setae; palp 2-articulate with three distal-lateral setae and row of six apical setae. Maxilla 2 external lobe with six apical setae; inner lobe with five apical setae. Left mandible incisor 5-toothed, lacinia mobilis 5-toothed and two accessory plates, row of 12 lateral setae, palp 3-articulate, first article with two distal setae, setal formula of last article 1-2-1-1; right mandible with incisor 5-toothed, lacinia mobilis 5-toothed with two accessory 
plates. Maxilliped inner plate with one subdistal robust seta and two robust setae on center-distal portion, outer lobe longer than inner lobe, with row of five lateral setae, palp article two enlarged with row of about 14 setae, article 3 with distal crown of setae.

THORAX. Gnathopod 1, ischium subquadrate, merus with lateral and ventral setae, carpus about two times as long as merus, propodus upper border rectilinear, ventral border with acute projection enclosing four robust proximal setae, palm with line of robust setae, dactylus smooth. Male morphotype I: gnathopod 2 merus about as long as carpus, propodus with small proximal indent with two robust setae, palm armed with scarce, small setae, slightly membranous, lobes absent. Pereopod 3, propodus not recurved at center, with 4-5 robust setae. Pereopod 4 propodus subequal in shape to pereopod 3, with 4-5 setae. Male morphotype II: gnathopod 2 merus two times as long as carpus, propodus 'bulked'; proximal indent with three robust setae; palm with 3-4 large visible membranous lobes, dactylus smooth and strongly recurved. Pereopod 3 propodus slightly recurved at center (Fig. 4) with 4-5 robust setae in two rows, occasionally with single, robust seta located at center. Pereopod 4 propodus less strong than pereopod three with 4-5 setae. Pereopods 5-7 missing in examined adults.

AвDOMEn. Proximal part slightly projected with one pair of 1-articulate pyriform appendages, two pairs of 2-articulate appendages and one pair of lobes. Abdomen tip smooth.

Female. $9.8 \mathrm{~mm}$. Body smooth. Gill plates present on pereonites 2-4. Oostegites reaching end of pereopods 3-4 basis. Gnathopod 1 merus and carpus slightly setose, propodus ventral-lateral margin with fringe of slender setae. Proximal projection with two robust and one slender seta, propodus palm with row of small robust setae and small projections, dactylus serrate. Gnathopod 2 carpus minute, much smaller than merus, propodus nearly elliptical, more than two times as long as wide, with acute ventral projection and three robust setae, palm of gnathopod two membranous lobes absent, dactylus smooth. Pereopod 3 propodus with three robust setae at center, row of minute distal setae, sometimes not visible. Pereopod 4 similar to 3. Pereopods 5-7 not present in any of adult individuals examined.

\section{Distribution (Figs 6-7)}

Type locality: North Atlantic, Zeeland (Krapp-Schickel 1993). Atlantic Ocean: Norway, Canary Islands, Azores, West Africa, South Africa (McCain 1968). Gulf of Mexico (Winfield et al. 2006, LeCroy et al. 2009); Florida, West Coast to Panama, Caribbean Sea, Cuba (Ortíz \& Lalana 2010, Martin et al. 2013), Venezuela (Díaz et al. 2005), Colombia (McCain 1968), Southern Iberian Peninsula (Conradi et al. 1997); North Africa (McCain 1968). Brazil: Bahia - Abrolhos Bank (Young \& Serejo 2005); Rio de Janeiro - Angra dos Reis (Quitete 1979 as P verae), Arraial do Cabo (Serejo 1998), Campos Basin (Mauro \& Serejo, 2015, present study); São Paulo - Enseada do Flamengo, Ubatuba (Quitete 1979 as P.verae); Santa Catarina - Ilha do Arvoredo (present study), Barra do Sul, Florianópolis (Lacerda \& Masunari 2011). Mediterranean Sea: France, Monaco, Sardinia, Italy (Thyrrhenian Sea), Sicily, Malta, Italy-Ionian Sea, Yugoslavia, Israel (Krapp-Schickel 1993). Depth range: 3 to $1470 \mathrm{~m}$ (see Winfield et al. 2006 for slope records).

\section{Ecological notes}

Phtisica marina has been collected in plankton and benthos samples (McCain 1968) on soft bottom (Winfield et al. 2006), but all material herein examined is from benthos samples. Phtisica marina is associated with a diverse type of substrates, e.g., sponge Dysidea (Wakabara \& Serejo 1998), algae Amphiroa beauvoissi (Lacerda \& Masunari 2011), Posidonia (with hydroids and Bryozoa), Aterias (Asteroidea) (Krapp-Schickel 1993). 


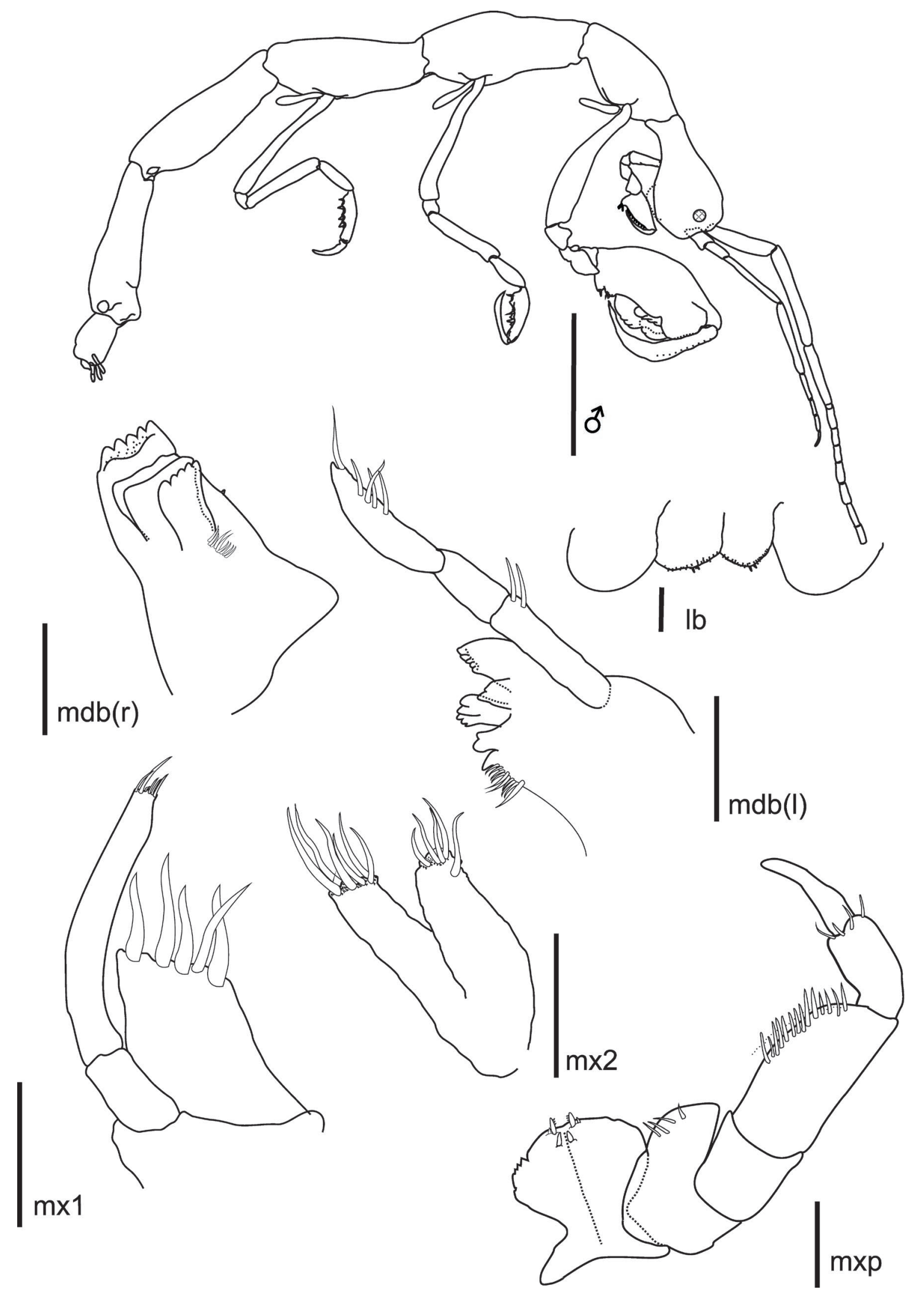

Fig. 3. Phtisica marina Slabber, 1769. Male morphotype II, $12.2 \mathrm{~mm}$, Angra dos Reis, RJ (CDZRJ 1014). Scale bars: habitus $=0.5 \mathrm{~mm} ; \mathrm{lb}, \mathrm{mx} 1, \mathrm{mx} 2, \mathrm{mdb}(1), \mathrm{mdb}(\mathrm{r}), \mathrm{mxp}=0.1 \mathrm{~mm}$. 


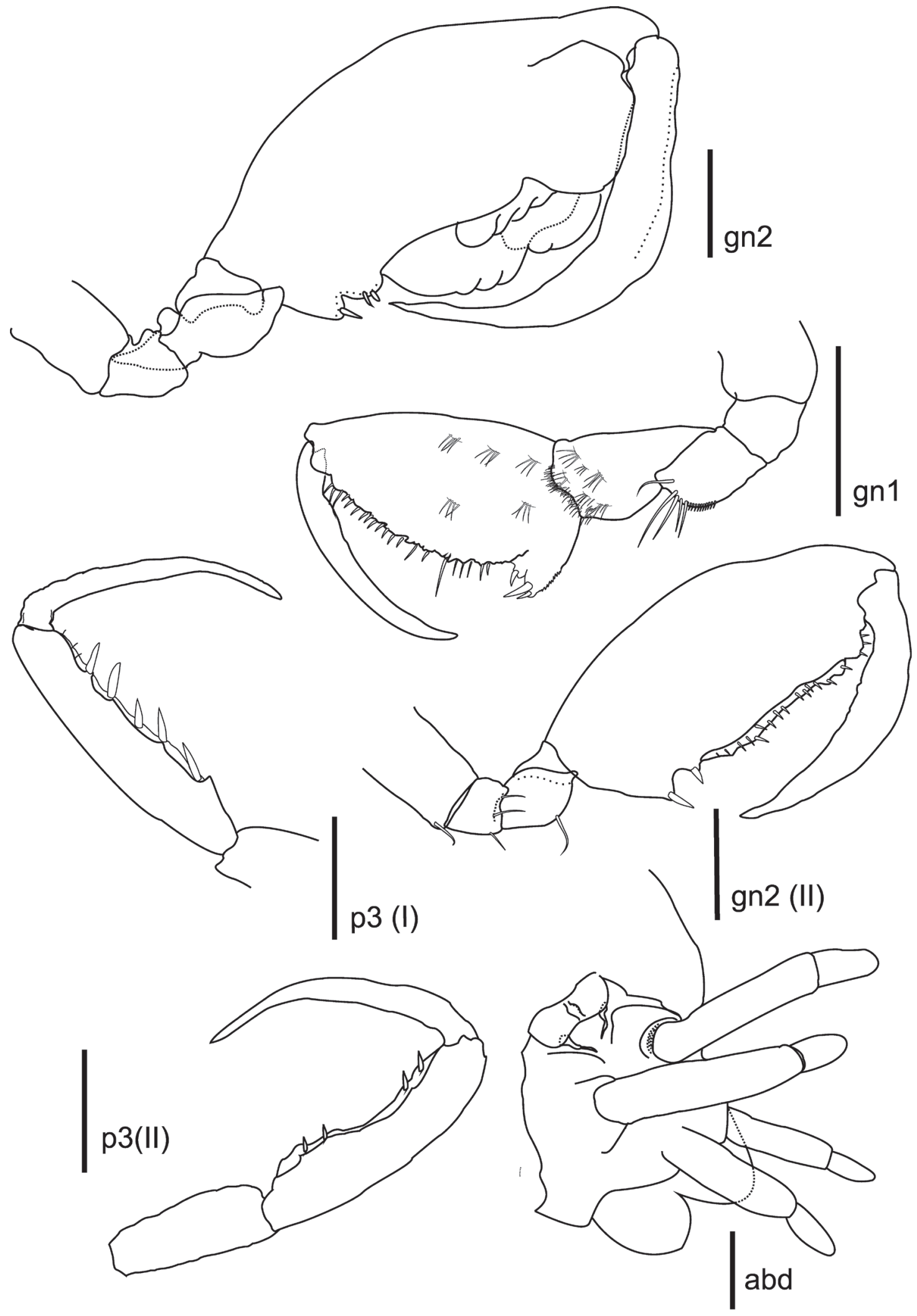

Fig. 4. Phtisica marina Slabber, 1769, $12.2 \mathrm{~mm}$, Angra dos Reis, RJ (CDZRJ 1014). Adult male morphotype I, $11.7 \mathrm{~mm}$, Campos Basin (MNRJ23483). Scale bars: gn2 $=0.3 \mathrm{~mm}$; gn1, p3, p4, $\mathrm{abd}=0.1 \mathrm{~mm}$. 

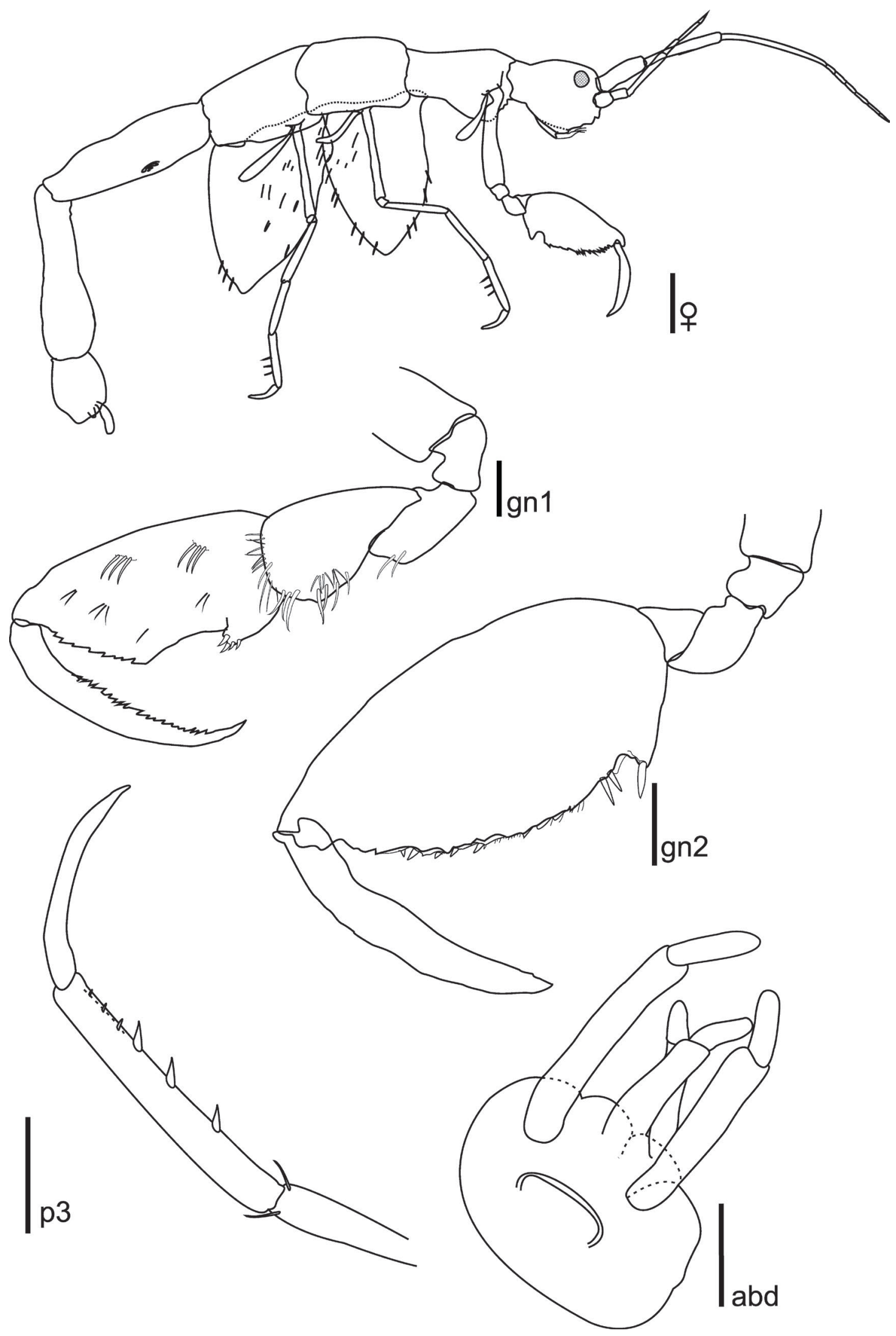

Fig. 5. Phtisica marina Slabber, 1769. Female, $7.9 \mathrm{~mm}$, Angra dos Reis, RJ (CDZRJ 1012). Scale bars: habitus $=1.0 \mathrm{~mm}$; gn1, gn2, p3, abd $=0.1 \mathrm{~mm}$. 


\section{Discussion}

Hemiproto wigleyi was first described by McCain (1968) who stated that the mandible setal formula is very similar to that of Phtisica, which is confirmed in the present study, regarding mandible setal formula (1-5-1 pattern for both Phtisica and Hemiproto). Despite the resemblances, Hemiproto differs from Phtisica in the maxilliped plates armed (versus unarmed), gnathopod 2 basis more than three times as long as pereonite 2 (versus up to 1.5 times) and male abdomen with two pairs of 1-articulate appendages (versus two pairs of 2 -articulate +1 rudimentary).

The present species matches the original description in the following characters: antenna 1 approximately equal to body length, antenna 2 reaching slightly beyond antenna 1 article 2, outer lobe of maxilla 2 with four strongly toothed setae, gnathopod 1 palm finely serrate and dactylus smooth, gnathopod 2 carpus length subequal to basis, pereopods 3-4 with two robust distal setae and male with two abdominal appendages 1-articulate. Small variations, regarding the original species description of McCain (1968), were observed such as: mandibular palp setal formula varying from 1-2-4-1 to 1-2-3-1 (versus 1-2-1).

This work presents the first record of $H$. wigleyi for the southwestern Atlantic Ocean (Figs 6-7).

Phtisica verae was originally described by Quitete (1979) from Angra dos Reis, Rio de Janeiro and Enseada do Flamengo, Ubatuba, São Paulo and has since then not been recorded from the Brazilian coast. The type material was accessed and compared with the material of Phtisica from Brazil deposited in the Crustacean Collection of the Museu Nacional/UFRJ. The present study acknowledges the existence of two male morphotypes of $P$. marina that were overlooked in Quitete's original description. Quitete (1979) described the following diagnostic characters for $P$. verae gnathopod 2, "carpus shorter than merus, propodus with greatest width at mid-length, presenting an irregular membrane at male's palm margin, with proximal spines". When observing the type material, we noticed that the carpus of the male gnathopod 2 is not considerably smaller in all specimens, only in the holotype P. verae

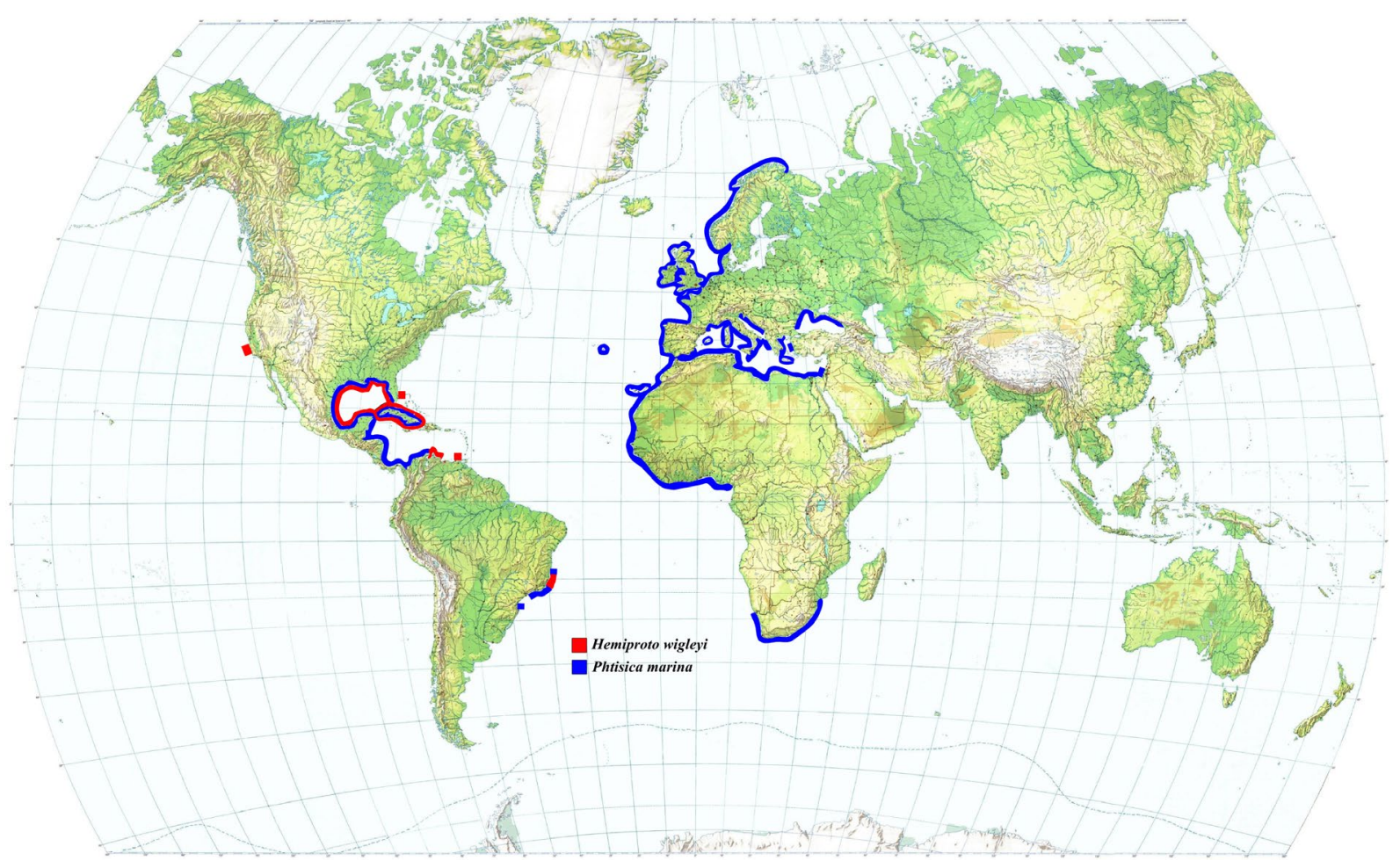

Fig. 6. World distribution of Phtisica marina Slabber, 1769 and Hemiproto wigleyi McCain, 1968. 
(0.5 times length of merus), but also in other material of Phtisica. Quitete (1979) pointed out some differences between $P$. verae and $P$. marina: 1$)$ male antenna 2 longer than antenna 1 peduncle; 2 ) mandible setae not serrate (versus serrate); 3) maxilliped inner plate smaller than outer plate (versus subequal or longer); 4) male gnathopod 1 propodus with 3 robust proximal setae (versus four robust setae and dactylus smooth); 5) male gnathopod 2 propodus with one robust seta, two proximal minute setae and an irregular membrane (versus two proximal robust setae, without membrane); 6) pereopods 3-4 with four grasping setae (versus three grasping setae). Examining the type material of $P$. verae and additional comparative material, we concluded that these differences are inconsistent to establish a new species based on the following observations 1) antenna 1 is considerably longer than antenna 2, varying according to size and development of individuals of $P$. verae (Figs 3, 5), which were also observed in P. marina, with antenna 2 varying from half-length or up to $3 / 4$ of antenna 1 peduncle; 2) morphology of mandible setae was essentially the same, all of them naked (not pectinate) as in the samples of $P$. marina. The setal formula showed a variation already observed by McCain (1968) (1-2-1 to 1-6-1), having a setal formula of individuals with $1-2-1$ or $1-3-1 ; 3$ ) maxilliped inner plate is subequal in length to outer plate, including Quitete's material, differing only from $P$. antillensis; 4) male gnathopod 1 propodus has four robust proximal setae as described for P. marina. McCain (1968) suggests a range from 4-5 setae while Krapp-Schickel (1993) reported five proximal setae; 5) gnathopod 2 (morphotype II), propodus with three robust proximal setae and three membranous lobes; 6 ) adult males of $P$. marina showed five

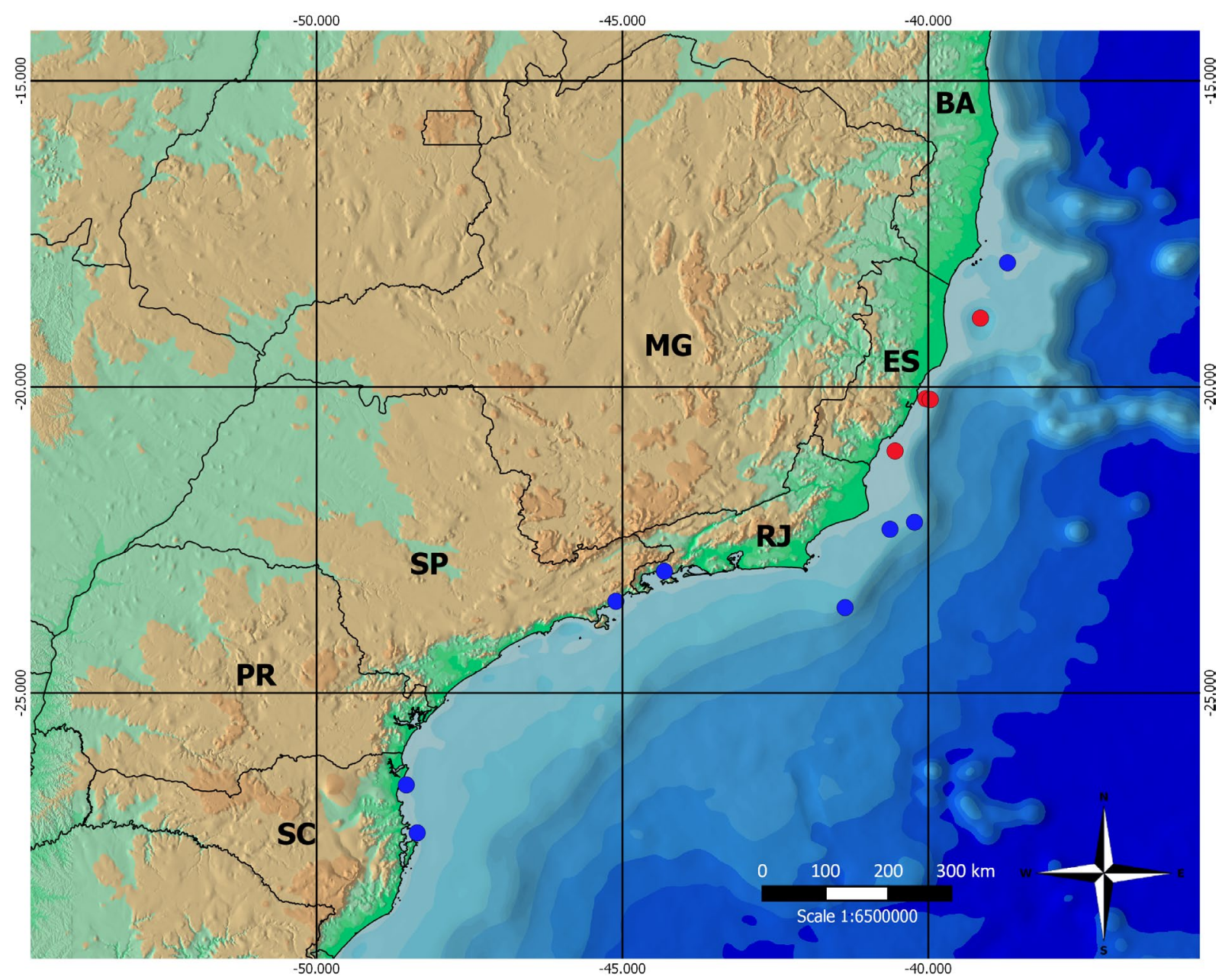

Fig. 7. Distribution of Phtisica marina Slabber, 1769 (blue dots) and Hemiproto wigleyi McCain, 1968 (red dots) along the Brazilian coast. Abbreviations: $\mathrm{BA}=$ Bahia; $\mathrm{ES}=$ Espírito Santo; $\mathrm{RJ}=$ Rio de Janeiro; SP = São Paulo; PR = Paraná; SC = Santa Catarina. 
to six robust setae on pereopods 3 and 4, while younger specimens showed three to four setae, therefore we noticed that this character is age dependent and should be used with caution. Moreover, adult males (morphotype II) show a unique recurved shape of pereopod 3 propodus.

In conclusion, Quitete (1979) described the morphotype II as a new species, but she overlooked some intraspecific variation and characters of morphotype II already observed by Sars (1895) and later on by Krapp-Schickel (1993) for $P$. marina. Based on these observations, the authors propose that $P$. verae is a junior synonym of $P$. marina and the genus now includes only two species, $P$. marina and $P$. antillensis.

Phtisica marina differs from $P$. antillensis by male gnathopod 2 carpus 0.5 times as long as than merus (versus two times longer), palm indent located at proximal part of propodus (versus medial) and pereopods 3 and 4 propodus with 4-5 setae in both sexes (versus lacking setae).

Phtisica marina was first described by Slabber (1769) with simple illustrations. The setal formula postulated by McCain (1968), ranging from 1-1-1 to 1-6-1 is in accordance to all specimens observed. Male gnathopod 1 with 4-5 setae grasping setae is in accordance to McCain (1968) and Krapp-Schickel (1993). The present material presents male gnathopod 2 with two morphotypes (Fig. 4). Sars (1895) also described male gnathopod 2 with two morphotypes, being 'type I' with three membranous lobes as the present material. McCain (1968) described only male 'type II', whereas Krapp-Schickel (1993) also illustrated male gnathopod 2 with two morphotypes, with no morphotype designations. Regarding pereopods 3-4, McCain (1968) and Krapp-Schickel (1993) pointed out three small setae on the propodus and Sars (1895) described four robust setae. Nevertheless, the present material shows 3-5 setae, which suggests that this variation range should be added to the species diagnosis. None of afore-mentioned taxonomic works correlates variations in Phtisica marina morphology to its geographical distribution.

Variations in male amphipods behavior and morphology have been observed in Jassa Leach, 1814 (Corophiida: Ischyroceridae), a mate-guarding amphipod genus, known to dissociate sexual activity from physiological maturity and to have dimorphic secondary sex characters in the male (Clark 1997). It is suggested that delay in sexual activity and dimorphism at maturity are responses to competition among males, thus creating different 'male types'. However, further studies on the ontogenetics of Phtisica marina are necessary to address such questions, as whether morphotypes correspond to late life-stages or constitute different individuals, which underlying events are involved, or how such variations may occur.

\section{Acknowledgements}

The authors are thankful to CENPES/PETROBRAS for coordination and providing material from the Projects HABIATS and AMBES.

Funding: This study was funded by CAPES (Coordenadoria de Aperfeiçoamento de Pessoal de Nível Superior) (Master Degree grant to first author no. 88882.156786/2017-01) and CNPQ (Conselho Nacional de Desenvolvimento Científico e Tecnológico) (Master Degree grant to second author process no. 312343/2015-9 and Productivity grant to last author process no. 312343/2015-9).

\section{References}

Barnard, J.L. \& Karaman, G.S. 1991. The families and genera of marine gammaridean Amphipoda (except marine gammaroids). Part 1. Records of the Australian Museum, Supplement, 13 (1): 1-417.

Clark K.A. 1997. Dimorphic males display alternative reproductive strategies in the marine amphipoda Jassa marmorata Holmes (Corophioidea: Ischyroceridae). Ethology 103: 531-553.

https://doi.org/10.1111/j.1439-0310.1997.tb00166.x 
Conradi M., López-González P.J. \& García-Gómez C. 1997. The amphipod community as a bioindicator in Algeciras Bay (Southern Iberian Peninsula) based on a spatio-temporal distribution. Marine Ecology 18 (2): 97-111. https://doi.org/10.1111/j.1439-0485.1997.tb00430.x

Dana J.D. 1853. Crustacea. Part II. In:United States Exploring Expedition During the Years 1838, 1839, 1840, 1841, 1842 Under the Command of Charles Wilkes. Vol. 14: 691-1618. Available from https://biodiversitylibrary.org/page/40412911 [accessed 17 Dec. 2019]. C. Sherman, Philadelphia.

Díaz Y.J., Guerra-García J.M. \& Martín A. 2005. The Caprellidea (Crustacea: Amphipoda) from Venezuela. Organisms Diversity \& Evolution 5: 249-251. https://doi.org/10.1016/j.ode.2004.11.010

d'Udekem d'Acoz C. \& Verheye M.L. 2017. Epimeria of the Southern Ocean with notes on their relatives (Crustacea, Amphipoda, Eusiroidea). European Journal of Taxonomy 359: 1-553.

https://doi.org/10.5852/ejt.2017.359

Horton T., Lowry J., De Broyer C., Bellan-Santini D., Coleman C.O., Corbari L., Daneliya M, Dauvin J.C., Fišer C., Gasca R., Grabowski M., Guerra-García J.M., Hendrycks E., Hughes L., Jaume D., Jażdżewski K., Kim Y.H., King R., Krapp-Schickel T., LeCroy S., Lörz A.N., Mamos T., Senna A.R., Serejo C., Sket B., Souza-Filho J.F., Tandberg A.H., Thomas J., Thurston M., Vader W., Väinölä R., Vonk R., White K. \& Zeidler W. 2018. World Amphipoda Database. Caprellidae Leach, 1814. Available from World Register of Marine Species http://www.marinespecies.org/aphia.php? $\mathrm{p}=$ taxdetails\&id=101361 [accessed 7 March 2019].

Ito A., Wada H. \& Aoki M.N. 2008. Phylogenetic analysis of caprellid and corophioid amphipods (Crustacea) based on the 18S rRNA gene, with special emphasis on the phylogenetic position of Phtisicidae. Biological Bulletin 214: 176-183. https://doi.org/10.2307/25066674

Ito A., Aoki M.N., Yahata K. \& Wada H. 2011. Complicated evolution of the caprellid (Crustacea: Malacostraca: Peracarida: Amphipoda) body plan, reacquisition or multiple losses of the thoracic limbs and pleons. Development Genes and Evolution 221: 133-140. https://doi.org/10.1007/s00427-011-0365-5

Guerra-García J.M. 2006. Caprellidae (Crustacea: Amphipoda) from the Great Barrier Reef and adjacent localities. Records of the Australian Museum 58: 417-458.

https://doi.org/10.3853/j.0067-1975.58.2006.1451

Krapp-Schickel G. 1993. Suborder Caprellidea. In: Ruffo S. (ed.) Amphipoda of the Mediterranean. Part 3. Vol. 19: 577-809. Mémoires de 1'Institut océanographique, Monaco.

Lacerda M.B. \& Masunari S. 2011. Chave de identificação para caprelídeos (Crustacea, Amphipoda) ocorrentes no litoral dos Estados do Paraná e de Santa Catarina. Biota Neotropica 11 (3): 1-12.

https://doi.org/10.1590/S1676-06032011000300030

Laubitz D.B. 1976. On the taxonomic status of the family Caprogammaridae Kudrjaschov \& Vassilenko (Amphipoda). Crustaceana 31 (2): 145-150.

Laubitz D.B. 1993. Caprellidea (Crustacea: Amphipoda): towards a new synthesis. Journal of Natural History 27 (4): 965-976. https://doi.org/10.1080/00222939300770591

LeCroy S.E., Gasca R., Winfield I., Ortiz M. \& Escobar-Briones E. 2009. Amphipoda (Crustacea) of the Gulf of Mexico. In: Felder D.L. \& Camp D.K. (ed.) Gulf of Mexico-Origins, Waters, and Biota. Biodiversity: 941-972. Texas A\&M University Press, College Station, Texas.

Lowry J.K. \& Myers A.A. 2013. A Phylogeny and classification of the Senticaudata subord. nov. (Crustacea: Amphipoda). Zootaxa 3610 (1): 1-80. https://doi.org/10.11646/zootaxa.3610.1.1

Lowry J.K. \& Myers A.A. 2017. A Phylogeny and classification of the Amphipoda with the establishment of the new order Ingolfiellida (Crustacea: Peracarida). Zootaxa 4265 (1): 1-89.

https://doi.org/10.11646/zootaxa.4265.1.1 
Martín A., Díaz Y., Miloslavich P., Escobar-Briones E., Guerra-García J.M., Ortiz M. \& Klein E. 2013. Regional diversity of Amphipoda in the Caribbean Sea. Revista de Biología Tropical 61 (4): 1681-1720. http://www.ncbi.nlm.nih.gov/pubmed/24432528

Mauro F.M. \& Serejo C.S. 2015. The Family Caprellidae (Amphipoda: Caprelloidea: Caprellidae) from Campus basin, Southwestern Atlantic with a key of species occurring in Brazil. Zootaxa 4006 (1): 103127. https://doi.org/10.11646/zootaxa.4006.1.5

McCain J.C. 1968. The Caprellidae (Crustacea: Amphipoda) of the Western North Atlantic. Bulletin of the United States National Museum 278: 1-147. https://doi.org/10.5962/bhl.part.8960

McCain J.C. \& Steinberg J.E. 1970. Amphipoda I, Caprellidea I, Family Caprellidae. In: Gruner H.E. \& Holthuis L.B. (eds) Crustaceorum Catalogus: 1-78. Dr. W. Junk N.V., Den Haag.

Myers A.A. \& Lowry J.K. 2003. A phylogeny and a new classification of the Corophiidea Leach, 1814 (Amphipoda). Journal of Crustacean Biology 23 (2): 443-485.

https://doi.org/10.1163/20021975-99990353

Oliveira L.P.H. 1940. Contribuição ao conhecimento dos Crustáceos do Rio de Janeiro. Catálogo dos Crustáceos da Baía de Guanabara. Memórias do Instituto Oswaldo Cruz 35 (1): 137-151.

Ortíz M. \& Lalana R. 2010. Distribución de los anfípodos (Crustacea, Malacostraca, Peracarida) de los subórdenes Gammaridea, Caprellidea e Hyperiidea, presentes en el archipiélago cubano. Revista de Investigaciones Marinas 31: 75-90.

Quitete J.M.P.A. 1979. Phtisica verae, nova espécie de Caprellidae (Crustacea: Amphipoda) da costa brasileira. Avulso do Departamento de Zoologia, Instituto de Biologia, Universidade Federal do Rio de Janeiro 32: 10-42.

Ribeiro-Ferreira V.P., Curbelo-Fernandez M.P., Filgueiras V.L., Mello R.M., Falcão A.P.C., Disaró S.T., Mello e Sousa S.H., Lavrado H.P., Veloso V.G., Esteves A.M. \& Paranhos R. 2017. Métodos empregados na avaliação do compartimento bentônico da Bacia de Campos. In: Falcão A.P.C. \& Lavrado H.P (eds) Ambiente bentônico: caracterização ambiental regional da Bacia de Campos, Atlântico Sudoeste: 1539. Rio de Janeiro.

Sars G.O. 1895. Amphipoda. In: An Account of the Crustacea of Norway With Short Descriptions and Figures of All the Species. Vol. 1. Mallingske Bogtrykkeri, Christiania and Copenhagen.

Serejo C.S. 1998. Gammaridean and caprellidean fauna (Crustacea) associated with the sponge Dysidea fragilis Johnston at Arraial do Cabo, Rio de Janeiro, Brazil. Bulletin of Marine Science 63 (2): 363-385.

Serejo C.S. \& Siqueira S.G.L. 2018. Catalogue of the Order Amphipoda from Brazil (Crustacea, Peracarida): Suborders Amphilochidea, Senticaudata and Order Ingolfiellidea. Zootaxa 4431 (1): 1-139. https://doi.org/10.11646/zootaxa.4431.1.1

Slabber M. 1769. Natuurkundige Verlustigingen, behelzende microscopise waarneemingen van in-en Uitlandse Water-en Land-Dieren. J. Bosch, Haarlem, Nederland.

Takeuchi I. 1993. Is the Caprellidea a monophyletic group? Journal of Natural History 27 (4): 947-964. https://doi.org/10.1080/00222939300770581

Takeuchi I. \& Lowry J.K. 2015. Taxonomic study on the Phtisicidae (Crustacea: Amphipoda) of New South Wales, Australia. Journal of Natural History 50 (9-10): 603-648.

https://doi.org/10.1080/00222933.2015.1079338

Verheye M., Martin P., Backeljau T. \& d'Udekem d'Acoz C. 2015. DNA analyses data reveal abundant homoplasy in taxonomically important morphological characters of Eusiroidea (Crustacea, Amphipoda). Zoologica Scripta 45 (23): 300-321, appendices S1, S2, S3. https://doi.org/10.1111/zsc.12153 
Wakabara Y. \& Serejo C.S. 1998. Malacostraca - Peracarida. Amphipoda. Gammaridea and Caprellidea. In: Young P.S. (ed.) Catalogue of Crustaceans of Brazil: 561-594. Série Livros 6. Museu Nacional/ Universidade Federal do Rio de Janeiro, Rio de Janeiro.

Watling L. 1997. The Suborder Caprellidea. In: Blake J.A. \& Scott P.V. (eds) Taxonomic Atlas of the Benthic Fauna of the Santa Maria Basin and Western Santa Barbara Channel Vol.12. The Crustacea Part 3: The Amphipoda: 223-240. Santa Barbara Museum of Natural History, Santa Barbara.

Winfield I., Escobar-Briones E. \& Morrone J.J. 2006. Updated checklist and identification of areas of endemism of benthic amphipods (Caprellidea and Gammaridea) from offshore habitats in the SW Gulf of Mexico. Scientia Marina 70 (1): 99-108. https://doi.org/10.3989/scimar.2006.70n199

Winfield I. \& Ortíz M. 2013. The Caprellidea (Crustacea: Peracarida: Amphipoda) from the Gulf of Mexico with a description of a new species of Paracaprella. Scientia Marina 77 (1): 161-168.

Young P.S. \& Serejo C.S. 2005. Crustacea of the Abrolhos Region, Brazil. In: Dutra G.F., Allen G.R., Werner T., McKenna S.A. (ed.) A Rapid Marine Biodiversity Assessment of the Abrolhos Bank 39: 91-95. Bahia, Brazil. RAP Bulletin of Biological Assessment, Conservation International.

Manuscript received: 24 May 2019

Manuscript accepted: 22 August 2019

Published on: 23 January 2020

Topic editor: Rudy Jocqué

Desk editor: Marianne Salaün

Printed versions of all papers are also deposited in the libraries of the institutes that are members of the EJT consortium: Muséum national d'histoire naturelle, Paris, France; Botanic Garden Meise, Belgium; Royal Museum for Central Africa, Tervuren, Belgium; Royal Belgian Institute of Natural Sciences, Brussels, Belgium; Natural History Museum of Denmark, Copenhagen, Denmark; Naturalis Biodiversity Center, Leiden, the Netherlands; Museo Nacional de Ciencias Naturales-CSIC, Madrid, Spain; Real Jardín Botánico de Madrid CSIC, Spain; Zoological Research Museum Alexander Koenig, Bonn, Germany; National Museum, Prague, Czech Republic. 